\section{Andrzej Kubanowski}

Uniwersytet Mikołaja Kopernika, Toruń

e-mail: a.kubanowski@gmail.com

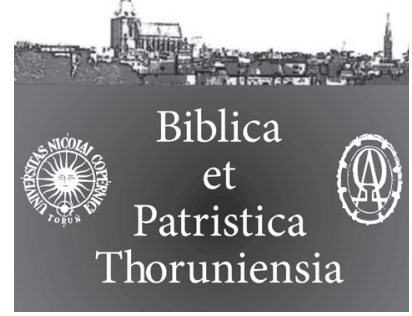

8 (2015) 1 ISSN 1689-5150

\title{
Nam frater est, et quantum ad generationem gratiae... - Analiza chrystianologiczna Listu do Filemona w świetle Super Epistolam B. Pauli ad Philemonem lectura św. Tomasza z Akwinu
}

\section{Nam frater est, et quantum ad generationem gratiae... - Christianological Analysis of Epistle to the Philemon in the Light of St. Thomas Aquinas's Super Epistolam B. Pauli ad Philemonem lectura}

Streszczenie. Artykuł przedstawia jeden ze sposobów przeprowadzenia analizy chrystianologicznej Listu do Filemona w oparciu o komentarz Tomasza z Akwinu. Już na samym początku przybliżone zostaje pojęcie chrystianologii oraz zasadność stosowania tego terminu w odniesieniu do pism Corpus Paulinum. Przedstawione zostaje także uzasadnienie wykorzystania komentarza Akwinaty. W dalszej części artykułu znajduje się krótka charakterystyka metody analizy chrystianologicznej oraz syntetyczny opis elementów właściwych Tomaszowej egzegezie. Zasadnicza analiza wybranych wersetów Listu do Filemona oscyluje wokół takich zagadnień jak chrześcijańskie braterstwo; naturalne i nadnaturalne pochodzenie owych więzi braterskich; relacje wewnątrz wspólnoty kościelnej; kwestia posłuszeństwa. W ramach podsumowania zostaje ukazana perspektywa Łaski Ducha Świętego, która stanowi konieczny element dla nowego stanu ontyczno-moralnego chrześcijan. W jego horyzoncie należy postrzegać przywoływane podczas analizy zagadnienia.

\begin{abstract}
The article presents one line of Epistle to the Philemon's christianological analysis based on St. Thomas Aquinas's commentary. In the beginning it is explained the term "christianology" and its use in reference to the Pauline epistles. Also it is argued that the use of Aquinas's commentary is indicated in these context. The next part of article contains short characterisation of christianological analysis method and presentation of specific elements of St. Thomas's exegesis. The main analysis of selected verses concerns the issues such as: Christian fraternity; natural and preternatural descent of this fraternity; relationship in ecclesial community; question of obedience. In summary it is set out the perspective of Holy Ghost's Grace, which is necessery ele-
\end{abstract}


ment for new ontic and moral Christian state. In this perspective are considered abovementioned issues.

Słowa klucze: chrystianologia; komentarz Tomasza z Akwinu; łaska; List do Filemona; braterstwo.

Keywords: christianology; St. Thomas Aquinas's commentary; grace; Epistle to the Philemon; fraternity.

Tnspiracją dla poniższych rozważań stał się artykuł ks. prof. Mirosława Mroza, pt: „Nova vita in Christo. Elementy chrystianologii moralnej św. Tomasza z Akwinu w świetle Wykładu Listu do Kolosan"1. We wprowadzeniu do analizy treści Tomaszowego komentarza ks. prof. M. Mróz stara się zarysować podstawy terminologiczne oraz uzasadnić rozpatrywanie nauki teologicznomoralnej Akwinaty w perspektywie chrystianologicznej. Samo pojęcie chrystianologii jako nauki o chrześcijaninie nie doczekało się jeszcze wystarczającego opracowania pod kątem pełnego zdefiniowania tego terminu. Na gruncie teologii polskiej pewien zarys, jak i metodologiczne podstawy znajdują się w książce o. Romana S. Zdziarstka OP, pt: „Chrystianologia Świętego Pawła, Aspekt ontyczny”2. Tamże autor mianem „chrystianologii” określa „naukę o chrześcijaninie opartą na Objawieniu Bożym, ujmującą go w relacji do Boga Ojca, Jezusa Chrystusa i Ducha Świętego" 3 . Przedmiotem tej dyscypliny nie jest więc bliżej nieokreślony człowiek, lecz chrześcijanin charakteryzowany w ontyczno-moralnym odniesieniu do Trójosobowego Boga ${ }^{4}$. O. Zdziarstek analizując wybrane fragmenty ze zbioru epistolarnego św. Pawła interpretuje je w kluczu chrystia-

1 Zob. M. Mróz, Nova vita in Christo, s. 321-356.

2 Zob. R.S. Zdziarstek, Chrystianolgia Świętego Pawła, Aspekt ontyczny, t. I, ss. 270.

3 Ibidem, s. 34-35: neologizm pochodzi od słów Xpıбı nauka, słowo, wiedza. Pierwszy człon w różnych formach gramatycznych trzykrotnie pojawia się na kartach Nowego Testamentu, zawsze na określenie wyznawców Jezusa Chrystusa.

4 Ibidem, s. 35-36: Nie jest to także antropologia biblijna, gdyż przedmiot chrystianologii jest zawężony wyłącznie do grupy chrześcijan, czyli ludzi, którzy najogólniej ujmując przyjęli Jezusa Chrystusa jako Zbawiciela, a fakt ten określa ich stan ontyczny i moralny. Trochę inne spojrzenie na temat umiejscowienia „chrystianologii” w zbiorze nauk teologicznych prezentuje protestancki teolog Emmanuel L. Rehfeld, który uważa „chrystianologię" za jeden z dwóch szczegółowych nurtów antropologii teologicznej, występujących w Listach Pawłowych. Drugim jest tzw. „hamartologia” lub „hamartiologia”, której przedmiot stanowi człowiek będący antytezą chrześcijanina - grzesznik, nieochrzczony. Zob. E.L. Rehfeld, Relationale Ontologie bei Paulus: die ontische Wirksamkeit der Christusbezogenheit im Denken des Heidenapostels, s. 119-125 
nologicznym, w którym szczególny akcent zostaje położony na sformułowania określające status ontyczny wyznawcy Chrystusa ${ }^{5}$. Potwierdzają one istnienie przestrzeni ontycznej, w której ludzkie esse otrzymuje nową jakość na skutek spotkania rzeczywistości Trynitarnego Boga. Jednak ten nowy status ontyczny ze swej istoty domaga się nieustannego urzeczywistniania na poziomie egzystencjalnym ${ }^{6}$. Owa ontyczna nowość manifestuje się więc poprzez sposób chrześcijańskiego życia. O tym sposobie deliberuje teologia moralna, której jednym z podstawowych zadań jest zapobieganie przed swoistą dezintegracją pomiędzy stanem ontycznym a stanem moralnym w człowieku. Właśnie dlatego możliwa jest chrystianologia moralna, która bazując na źródłach nowotestamentalnych w centrum swoich rozważań stawia bycie chrześcijaninem.

Tutaj rodzi się pytanie, dlaczego akurat komentarze do Corpus Paulinum św. Tomasza z Akwinu? Odpowiadając na nie: po pierwsze, Listy św. Pawła stanowią źródło dla chrystianologii Nowego Testamentu. Wynika to ze swoistości owych pism, które powstawały w łonie, a także na użytek gmin wczesnochrześcijańskich. Stąd też dotykają spraw przynależących do istoty bycia chrześcijaninem, określając ją zarówno od strony statusu ontycznego, jak i zachowań moralnych, częstokroć również przedstawiając je w kontraście do rzeczywistości niechrześcijańskiej ${ }^{7}$. Po drugie, Akwinata swoją myśl teologicznomoralną konstruuje na fundamencie biblijnym. Szczególne miejsce zajmuje w nim epistolarny zbiór Pawła Apostoła, z którego, pomimo pewnych różnic dotyczących niektórych szczegółów, Doktor Anielski czerpie inspirację dla swojej koncepcji, opierając ją na fundamencie Łaski Ducha Świętego działającej w rzeczywistości stworzonej ${ }^{8}$. Wreszcie po trzecie, owa koncepcja teologicznomoralna Tomasza

5 Por. R.S. Zdziarstek, Chrystianologia Świętego Pawła, s. 36-47: Sformułowania te

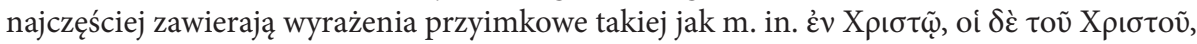

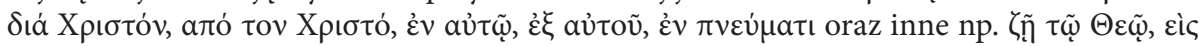
X

6 Przykładowe publikacje poszerzające owo zagadnienie: Cz. Bartnik, Ontyczne aspekty moralności chrześcijańskiej, s. 9-15; A. Derdziuk, Trynitarny fundament życia moralnego, s. 19-32; A. Gieniusz, Chrzcielne korzenie chrześcijańskiej proegzystencji wedtug Świętego Pawła, w: Agnus et sponsa, Prace ofiarowane o. prof. Augustynowi Jankowskiego OSB, s. 87-101; J. Nagórny, Trynitarny fundament życia moralnego w ujęciu św. Pawła, s. 47-56; A. Nossol, Chrystologia egzystencjalna, s. 73-88; J. Piegsa, Jezus Chrystus norma moralności chrześcijańskiej, s. 215-228; S. Warzeszak, Ontologiczno-egzystencjalne podstawy etosu Nowego Testamentu, s. 259-270.

7 Inne pisma Nowego Testamentu również zawierają treści chrystianologiczne, jednak nadal nie zostały one poddane wystarczającym analizom oraz rozważaniom w tym kontekście.

8 Zob. M. Mróz, Pawłowe „Prawo Ducha” (Rz 8,2) kluczem do zrozumienia myśli św. Tomasza $z$ Akwinu o istocie Ewangelii, s. 39. Tematyka wzajemnych odniesień myśli św. 
z Akwinu w swoim centrum zawiera także pytanie o istotę bycia chrześcijaninem. Do odpowiedzi podchodzi mając na uwadze szczególny, chrystyczny rys całej kwestii, którą opisują zagadnienia imitatio - „naśladowania” oraz conformitas - „upodobnienia” do Chrystusa. Niejako streszczającym responsem na pytanie o istotę bycie chrześcijaninem jest fragment z Summa Theologiae, II-II, q. 124 , a. 5 , ad $1^{9}$. Od razu da się w nim dostrzec chrystianologiczny charakter, który oscyluje wokół potrójnego odniesienia chrześcijanina do Łaski Ducha Świętego, do wiary chrzcielnej oraz do postępowania w dynamice cnót. Również poniższa analiza chrystianologiczna treści Listu do Filemona na kanwie Wykładu Akwinaty jest próbą odszukania i odsłonięcia tych wymiarów, które składają się na pełny obraz człowieka „chrystusowego” w refleksji chrystianologii moralnej ${ }^{10}$.

\section{Metoda analizy chrystianologicznej Akwinaty}

Zanim dokonana zostanie właściwa analiza chrystianologiczna, należy przedstawić jeszcze kilka zagadnień formalnych dotyczących metody analizy, a także samego Wykładu Listu. Owa metoda analizy chrystianologicznej w pierwszym rzędzie polega na odszukaniu w tekście biblijnym sformułowań lub całych fraz służących określaniu chrześcijanina oraz chrześcijańskiego życia w odniesieniu do Boga, do wspólnoty eklezjalnej, do drugiego człowieka, do świata i do samego siebie, zarówno $\mathrm{w}$ aspekcie ontycznym, jak i moralnym ${ }^{11}$. Następnie wyselekcjonowane fragmenty zostają poddane interpretacji według Wykładu Tomasza z Akwinu, który będzie stanowić podstawowe narzędzie hermeneutyczne, zarysowujące również ramy interpretacyjne dla innych opracowań pomocniczych, w tym Sumy teologicznej, pozostałych dzieł Akwinaty oraz współczesnych komentarzy.

Tomasza z Akwinu oraz św. Pawła Apostoła, ze wskazaniem również na różnicę pomiędzy nimi, znajduje się m.in. w: S.T. Pinckaers, Życie duchowe chrześcijanina według św. Pawła $i$ św. Tomasza $z$ Akwinu, ss. 339.

9 S.Th., II-II, q. 124, a. 5, ad 1: „Christianus dicitur qui Christi est. Dicitur autem aliquis esse Christi non solum ex eo quod habet fidem Christi, sed etiam ex eo quod spiritu Christi ad opera virtuosa procedit", etc.

10 Por. M. Mróz, Nova vita in Christo, s. 324-325.

11 Klucz, według którego dokonuje się doboru odpowiednich fragmentów został częściowo opracowany przez R.S. Zdziarstka w „Chrystianologia Świętego Pawła”, a także poszerzony przez M. Mroza w „Nova vita in Christo. Elementy chrystianologii moralnej św. Tomasza z Akwinu w świetle Wykładu Listu do Kolosan” oraz jego innych publikacjach dotyczących chrystianologii. 
Pozostając jeszcze na płaszczyźnie zagadnień formalnych wypada odnieść się do samego komentarza Listu do Filemona przypisywanego św. Tomaszowi z Akwinu. Na samym początku trzeba odnotować, że stanowi on formę reportatio wykładu Akwinaty przygotowanego prawdopodobnie przez Reginalda z Piperno ${ }^{12}$. Mimo iż jest najkrótszy z całego zbioru Super Epistolas S. Pauli lectura, to zawiera w sobie wszystkie cechy charakteryzujące biblijną egzegezę św. Tomasza. Metody egzegetycznej, którą stosuje Doktor Anielski, nie da się określić jednym, technicznym terminem ${ }^{13}$. Ma ona bowiem charakter wieloaspektowy, zasadzający się na korelacji pomiędzy metafizyką a hermeneutyką biblijną. W ramach rozwinięcia tego tematu rzeczone aspekty zostaną tutaj tylko zarysowane, gdyż ich szczegółowa charakterystyka oraz dogłębna analiza nie są głównym celem niniejszego artykułu.

Pierwszym aspektem właściwym dla Tomaszowego podejścia do interpretacji tekstu Pisma Świętego jest autorytet (auctoritas) i wynikający z niego argument (ratio). Głównym celem przywołania autorytetu jest dostarczenie twierdzenia (opinio) oraz złożenie na nim odpowiedzialności (missio) za to, że treść przekazu jest zgodna z prawdą obiektywną ${ }^{14}$. Dlatego też auctoritas podlega pewnemu stopniowaniu. Najważniejszym jest Auctoritas divina, który pochodzi bezpośrednio od Boga. Oprócz właściwości ostatecznego rozsądzenia specyfikuje się również tym, że jest przyczyną dobra w człowieku' ${ }^{15}$. Kolejnym stopniem autorytetu jest Auctoritas Sacrae Scripturae, gdzie cytaty z Pisma Świętego odgrywają rolę nie tyle najważniejszych argumentów w rozwiązywaniu konkretnej kwestii, ile raczej „hermeneutycznej ścieżki”, po której można dotrzeć do coraz głębszych warstw sensu tekstu biblijnego ${ }^{16}$. Z tym zagadnie-

12 Por. M. Hanusek, Komentarz św. Tomasza z Akwinu do Listu do Filemona, s. 93; P. Roszak, Słowo od redaktora, Biblia i metafizyka: ku tomizmowi biblijnemu, s. 21; J.-P. Torrell, Tomasz z Akwinu - człowiek i dzieło, s. 299; J.A. Weisheipl, Tomasz z Akwinu. Życie, myśl i dzieło, s. 454-455. Reginald z Piperno był osobistym socjuszem i przyjacielem Tomasza z Akwinu, który spisywał niektóre z jego wykładów podczas pobytu w Italii w latach 1259-1268.

13 Użycie „metoda scholastyczna”" wydaje się tu pojęciem zbyt szerokim, zob. M. Levering, Ecclesial Exegesis and Ecclesial Authority: Childs, Fowl and Aquinas, s. 407-467: Autor ten proponuje mówić o stylu egzegezy Akwinaty, który nazywa „egzegezą eklezjalną”, „egzegezą kościelną”, posiadającym szczegółowe elementy odróżniające go od ówczesnych praktyk egzegetycznych.

14 Por. W. Świerzawski, Egzegeza spekulatywna i teologia spekulatywna św. Tomasza z Akwinu, s. 29-30; P. Roszak, Autorytet w poszukiwaniu mądrości, s. 73.

15 Por. P. Roszak, Autorytet w poszukiwaniu madrości, s. 77-79.

16 Ibidem, s. 79-80; P. Roszak, The Place and Function of Biblical Citations in Thomas Aquinas's Exegesis. 
niem ściśle wiąże się zasada locum ex loco, którą Tomasz z Akwinu stosował, gdy jeden z trudniejszych fragmentów Pisma Świętego wyjaśniał za pomocą innego fragmentu ${ }^{17}$. Ostatnim stopniem autorytetu jest Auctoritas docendi, który przynależy Ojcom Kościoła, z zastrzeżeniem, że nie ma on źródła w nich samych, lecz w autorytecie Kościoła, którego Tradycję reprezentują. Z tego powodu ich stanowisko winno być zgodne $\mathrm{z}$ nadrzędnymi auctoritas ${ }^{18}$.

Drugim aspektem charakteryzującym egzegezę Akwinaty jest tzw. translatio terminorum, czyli wyjaśnianie oraz uzgadnianie ze sobą terminów pochodzących z języka Biblii i języka filozofii. W wyniku wprowadzania do średniowiecznej egzegezy biblijnej rysu spekulatywnego w komentarzach znalazło się miejsce na questiones, a także elementy disputatio. U św. Tomasza szczególnie często pojawiają się one w ramach wykładów do Listów Pawłowych. Zawsze jednak są mocno osadzone na wcześniej wspomnianych autorytetach oraz ukierunkowane na cel egzegezy, którym jest doprowadzenie „do poprawnego wierzenie i prawego działania" ${ }^{19}$.

Ostatnim aspektem, który uwidacznia się w biblijnych komentarzach Akwinaty jest specyficzne podejście do zagadnień współcześnie znanych pod pojęciem krytyki tekstualnej. Pod wpływem rozpowszechnionej metody historyczno-krytycznej, niektórzy bibliści deprecjonują wartość aparatu krytycznego średniowiecznych mistrzów lub w ogóle odrzucają jego istnienie. Nie jest to jednak podejście właściwe. Należy przede wszystkim zaznaczyć, że tzw. scholastyczna krytyka tekstualna, którą spotyka się również w dziełach Tomasza z Akwinu nie ma na celu dotarcia do tekstu najbliższego oryginałowi, lecz odkrycia w dostępnym tekście pewnych założeń, implikujących się następnie w konkretnych postawach wiary i moralności. Nie oznacza to także, że św. Tomasz wykazywał się pewnego rodzaju brakiem troski o autentyczność źródeł.

17 Por. M. Mróz, P. Roszak, Tomasza z Akwinu, s. 128: „tę słynną zasadę - locum ex loco - stosował św. Tomasz zarówno przy poszczególnych problemach egzegetycznych, jak również gdy za pomocą wybranego fragmentu Pisma tłumaczył główny temat poszczególnych ksiąg". Zob. też P. Roszak, Exegesis y metafisica. En torno a la hermeneutica biblica de santo Tomas de Aquino, s. 322-323.

18 Por. M. Mróz, P. Roszak, Tomasza z Akwinu, s. 118-120; P. Roszak, Autorytet w poszukiwaniu mądrości, s. 81-83. Źródła myśli Ojców Kościoła dla Tomasza z Akwinu stanowiły liczne glossy, leksykony oraz ich dzieła własne. W komentarzu Listu do Filemona Akwinata powołuje się m. in. autorytety Orygenesa (nr 14), Augustyna (nr 28) i Jana Chryzostoma (nr 29). Znakomitym przykładem kompilacji podjeść różnych Ojców do Pisma Świętego jest Tomaszowa Catena Aurea do Czterech Ewangelii.

19 Thomae Aquinatis, Quodlibet VII, q. 6, a. 2 co: „scilicet ad recte credendum, et recte operandum”. Por. W. Świerzawski, Egzegeza spektulatywna, s. 30-32; P. Roszak, Between Dialectics and Metaphor, s. 509-510. 
W niektórych komentarzach przywołuje alternatywne wersje fragmentów Pisma Świętego. Głownie jednak bazuje na edycji Wulgaty zwanej „Biblią Paryską" (Textus Parisiensis) lub Biblią Świętego Jakuba (Biblia Paryska po dominikańskiej korekcie $)^{20}$. Podstawowym elementem owej krytyki tekstualnej jest divisio textus, czyli podział tekstu w celu określenia punktów wyjścia dla dalszej interpretacji. Podział ten przebiega według pewnego schematu, rozpoczynając się od tzw. divisio maior, dotyczącego generalnych części danego teksu. Najczęściej są to całe rozdziały komentowanej księgi lub listu, omawiane zazwyczaj w prologu, na początku każdego komentarza. W przypadku Listu do Filemona pierwszą część stanowią wersety od 1 do 9, zaś drugą od 10 do $25^{21}$. Zostanie to omówione $\mathrm{w}$ dalszej części artykułu. Po divisio maior następuje divisio minor, który bazuje na konkretnych zmianach zachodzących w tekście biblijnym. W liście zamiast zmiany miejsca akcji, bohaterów i czasu szczególna uwaga zostaje zwrócona ku pojawiającym się w treści nowym tematom, pojęciom oraz terminom $^{22}$. „Podział mniejszy” występuje w toku komentowania, zazwyczaj na początku aktualnie komentowanej sekcji tekstu (lectio). W odróżnieniu od współczesnego wyznaczania struktury tekstu divisio textus nie ma na celu dokonywania sztucznego podziału ingerującego w treść, ale raczej odkrycie istniejącej struktury, która komunikuje swój doktrynalny i teologiczny sens ${ }^{23}$.

To krótkie omówienie różnych aspektów egzegezy biblijnej św. Tomasza warto zakończyć przywołaniem jeszcze jednego elementu strukturalnego, który jednocześnie stanowić będzie dobre wprowadzenie do właściwej analizy chrystianologicznej. Owym elementem jest accessus, czyli wstęp do komentarza (zwany najczęściej prologiem) ${ }^{24}$. W prologu autor zarysowywał główne linie interpretacyjne, tematy oraz znaczenia kluczowych przedmiotów (postaci, wy-

20 Por. M. Mróz, P. Roszak, Tomasza z Akwinu, s. 124-126; M.G. Sirilla, St. Thomas Aquinas's Theology of the Episcopacy in his Commentaries on the Pastoral Epistles, s. 40. Zob. też G. Dahan, Les éditions des commentaires bibliques de saint Thomas d'Aquin, s. 9-15.

21 Współczesna propozycja struktury Listu do Filemona: 1. formuła otwierająca (1-3), 2. zapewnienie o modlitwie za adresata (4-7), 3. corpus listu - cześć główna (8-20), 4. zakończenie (21-25), za: B. Adamczewski, Nowy komentarz biblijny. List do Filemona, List do Kolosan, Częstochowa 2006, s. 42.

22 Por. M. Mróz, P. Roszak, Tomasza z Akwinu, s. 126-127; M.G. Sirilla, St. Thomas Aquinas's, s. 50.

23 Por. M.G. Sirilla, St. Thomas Aquinas's, s. 50-51; zob. też S.T. Pinckaers, Życie duchowe, s. 40-41.

24 Por. M. Mróz, P. Roszak, Tomasza z Akwinu, s. 127; M.G. Sirilla, St. Thomas Aquinas's, s. 51-52. Dla sprecyzowania, „prolog” odnosi się do początkowej części Wykładu Akwinaty, natomiast „proemium” odnosi się do początkowych wersetów Listu św. Pawła. Zob. też T. Gałuszka, Badania nad Biblia w XIII wieku, s. 67-70. 
darzeń, miejsc, czasu, okoliczności) znajdujących się w komentowanym tekście biblijnym. Tomasz z Akwinu posługiwał się także cytatem wprowadzającym (thema), który miał stanowić swoisty klucz hermeneutyczny dla rozumienia właściwej treści. W przypadku Wykładu Listu do Filemona jest to cytat Syr 33,31. Przez przywołanie tego wersetu główny temat Flm zasadza się na relacji podwładnego do przełożonego. Akwinata wskazuje jeszcze na trzy ścieżki interpretacyjne, które odnoszą się do tej relacji. Są nimi postawa sługi, którą powinna cechować wierność oraz postawa pana będącego przyjacielem i traktującego swojego podwładnego jak brata. Podstawa regulująca ich wzajemne stosunki jest podwójna, gdyż najpierw wynika z posiadania przez nich tej samej natury ludzkiej stworzonej przez Boga, a następnie jako chrześcijan, z pochodzenia z tej samej łaski (ad generationem gratiae) ${ }^{25}$.

Oś interpretacyjna komentarza generalnie skupia się na literalnym ${ }^{26}$ odczytaniu relacji pomiędzy panem a jego sługą. Natomiast jest w niej również uwzględniony sens duchowy ${ }^{27}$ oraz sens pełniejszy ${ }^{28}$ nowotestamentalnej epi-

25 S. Thomae Aquinatis, Super Epistolam B. Pauli ad Philemonem lectura, 1. 1, nr 1 [dalej: Super Philem.]: numeracja komentarza za: S. Thomae Aquinatis, Super Epistolas S. Pauli lectura, t. 2, Super Epistolam B. Pauli ad Philemonem lectura, s. 327-333.

26 Por. W. Świerzawski, Egzegeza spekulatywna, s. 36-37: „Punktem wyjścia dla jego egzegezy jest podwójne znaczenie litery Pisma św. - to które dotyczy słów (voces) i to które dotyczy rzeczywistości, wydarzeń (res). Pierwsze znaczenie jest literalne lub historyczne, drugie jest mistyczne lub duchowe"; P. Roszak, Between Dialectics and Metaphor, s. 514-515: Literalne odczytywanie sensu Pisma Świętego w egzegezie Tomasza z Akwinu nie polega bynajmniej na lekturze fundamentalistycznej. Chodzi zaś o takie odczytanie tekstu, które skupia się na znaczeniu poszczególnych wyrazów i sformułowań z uwzględnieniem ich kontekstu, gatunku literackiego, formy gramatycznej i stylistycznej (np. metafora nie jest odczytywana dosłownie, ale w sposób metaforyczny, który jest jej właściwy). Zob. też M. Healy, Aquinas's Use of the Old Testament in His Commentary on Romans, s. 183-184.

27 Zob. R. Cantalamessa, „Litera zabija, Duch ożywia”. Lektura duchowa Biblii, s. 273-285; S. Haręzga, En Pneumati jako zasada interpretacji Pisma św. we wschodniej tradycji Kościoła, s. 113-117: Biblia jest dziełem natchnionym przez Ducha Świętego, dlatego w procesie jej relektury i interpretacji potrzebna jest łaska Jego obecności. Istnieją jednak pewne kryteria, które pozwalają uznać daną interpretacje duchową za prawdziwą i zgodną z zamiarem Autora. Należą do nich: odkrywanie sensu duchowego na fundamencie sensu literalnego; trwanie w wierze Kościoła, czyli kryterium żywej i ortodoksyjnej Tradycji; kryterium jedności całego Pisma Świętego. Wszystkie one są spełnione również w Tomaszowej egzegezie.

28 Zob. S. Szymik, Współczesne modele egzegezy biblijnej, s. 60-61: Pojęcie jest stosowane od 1925 r. i oznacza sens Pisma Świętego, który został zamierzony przez Boskiego Autora, ale nie wyrażony jasno przez autora natchnionego. „Sens pełniejszy odkrywa się w wypowiedziach Biblii, gdy te zgłębiane są powtórnie w innych tekstach biblijnych albo gdy analizuje się je przez pryzmat wewnętrznego rozwoju objawienia w Kościele”. 
stoły. Na tej bazie zostanie przeprowadzona analiza chrystianologiczna Listu do Filemona, która powinna potwierdzić obecności treści chrystianologicznych w tym piśmie Apostoła Narodów. Już sam Prologus przygotowany przez Tomasza z Akwinu jasno na to wskazuje, kreśląc wyraźną analogię relacji sługa-pan a chrześcijanin-Chrystus ${ }^{29}$.

\section{FIm 1,1-9 (nr 3-14) $)^{30}$}

List do Filemona ${ }^{31}$, tak jak inne pisma Pawłowe rozpoczyna się klasycznym praescriptum, które zazwyczaj zawiera odniesienie do nadawcy, adresata i pozdrowienia. Warto zwrócić uwagę, że choć list jest skierowany do Filemona, to jednak przez przywołanie imion innych osób Apostoł nadaje mu charakteru eklezjalnego ${ }^{32}$. Kluczowymi dla poszukiwania treści chrystianologicznych są dwa epitety znajdujące się w początkowych wersetach: „brat” (Flm 1,1.7) oraz „święci” (Flm 1,5.7). Akwinata podkreśla, że w przypadku pierwszego nie chodzi o braterstwo biologiczne, ale o braterstwo w doskonałej wierze ${ }^{33}$. Ta doskonała wiara polega na całkowitym zwróceniu swojej aktywności ku rzeczywistości zbawienia, która jest w Jezusie Chrystusie. Nie tylko dla własnych korzyści i chwały, ale przez wzgląd na korzyści dla bliźnich, które mogą z tej doskonałości wiary wypływać oraz przez wzgląd na większą Chwałę Boża, by mogła się odsłaniać światu (por. Flp 2,20) ${ }^{34}$. Natomiast określenie „święci” jest bardzo

29 Zob. J. Gnilka, Paweł z Tarsu. Apostoł $i$ świadek, s. 354-355.

30 W związku z tym, że za główny komentarz zostało tu przyjęte dzieło św. Tomasza, dlatego zgodnie z jego strukturą zostaje pominięte współczesne wprowadzenie historyczno-krytyczne. Takie wprowadzenia można znaleźć m.in. w: B. Adamczewski, Nowy komentarz, s. 30-49; J.D.G. Dunn, The Epistles to the Colossians and to Philemon. A Commentary on the Greek Text, s. 299-309; J. Gnilka, Der Philemonbrief, s. 7-12; A. Jankowski, Listy Więzienne Świętego Pawła, s. 309-316; H. Langkammer, Komentarz teologiczno-pastoralny wszystkich listów św. Pawła Apostoła z okazji roku Świętego Pawła. Listy Więzienne św. Pawła, t. 2, s. 318-322; A. Paciorek, Paweł Apostot - pisma, cz. 1, s. 184-185.

31 Treść Listu do Filemona analizowana jest w niniejszym artykule na podstawie wersji Wulgaty znajdującej się w Super Epistolam ad Philemonem lectura, generalnie pokrywającej się z przekładem Clementine Vulgate $\left(\mathrm{vg}^{\mathrm{c}}\right)$ i polskimi tłumaczeniami (BT wyd.V, BG, BW).

32 Por. B. Adamczewski, Nowy komentarz, s. 53; H. Langkammer, Komentarz teologiczno-pastoralny, s. 323.

33 Super Philem., c.1, 1.1, nr 4.

34 S. Thomae Aquinatis, Super Epistolam B. Pauli ad Philipenses lectura, c. 2, nr 88-90. Cytaty biblijne wyjaśniające do danych wersetów Flm przywoływane za komentarzem św. Tomasza z Akwinu, chyba że zostało zaznaczone inaczej. 
mocno związane z terminem „chrześcijanie” i zazwyczaj, a w przypadku Listów Więziennych zawsze, pojawia się na początku każdego z pism Pawłowych. Jego znaczenie jest dwojakie. „Świętymi” mogą zostać nazwane osoby, które uwierzyły w bóstwo Chrystusa, zarówno na podstawie Jego osobistego nauczania lub dalszego świadectwa apostołów i uczniów, albo też wszystkich tych, którzy za bezpośrednimi świadkami, swoim życiem dalej głoszą Chrystusową Ewangelię. Dlatego chrześcijanie powinni wierzyć zarówno w słowa Pana, jak i nauczanie świętych, którymi stają się także oni (por. Hbr 2,3). Innym wariantem rozumienia terminu sancti, który może występować wspólnie z powyższym przedstawieniem jest ujęcie „świętych” jako ludzi obdarowanych różnorakimi darami wskutek wyznania wiary ${ }^{35}$. Dwa najważniejsze z owych darów pojawiają się już w dziękczynieniu Apostoła Pawła (Flm 1,4.7). Są nimi miłość i wiara, według Akwinaty określane jako dobra konieczne. Bowiem z powodu braku miłości chrześcijanin traci rozeznanie w rzeczywistości wartości, którymi są cnoty, dary oraz sam Bóg. Brak wiary uniemożliwia umiłowanie Boga, gdyż niemożliwe staje się Jego prawdziwe poznanie. Z dużym prawdopodobieństwem można stwierdzić, że przywołanie przez św. Pawła wiary i miłości odbywa się w kluczu trzech cnót teologalnych $(1 \text { Kor } 13,13)^{36}$. Nadzieja zostaje przez niego pominięta, gdyż w jakiś sposób jest już zapośredniczona w dwóch pozostałych $^{37}$. Stanowi ona formę niewydoskonalonej miłości, gdyż w niej miłuje się przedmiot nie przez wzgląd na niego samego, lecz na pragnienie dobra, które ten przedmiot może zaspokoić. Stąd też w miarę poznawania przedmiotu umiłowania nadzieja przekształca się w miłośćc ${ }^{38}$. Co, a raczej kto jest przedmiotem owej wiary i miłości? Paweł Apostoł odpowiada, że Jezus Chrystus (Flm 1,5-6). To jest drugi powód, dla którego Tomasz z Akwinu mówi o darach koniecznych dla chrześcijanina. Tylko z miłości do Chrystusa, jako Głowy Mistycznego Ciała, może pochodzić miłość do Jego członków. Jest to więc niezbędny warunek dla zaistnienia miłości wewnątrzeklezjalnej. Nie można przecież miłować samej głowy bez umiłowania członków tego samego ciała (por. J 4,20). W odniesieniu do wiary, tylko ta, która jest skierowana na Chrystusa może prowadzić

35 Super Philem., 1.1, nr 9; zob. też S. Thomae Aquinatis, Super Epistolam B. Pauli ad Colossenses lectura, c.1, nr 6: „Świętymi” mogą być określani przewodzący konkretnej wspólnocie eklezjalnej lub też w szerszym rozumieniu ci, którzy zostali uświęceni przez Chrzest św.

36 W trochę innym kontekście te trzy pojawiają się również w Ga 5,5-6 (nadzieja spra-

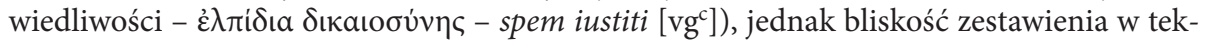
ście tych pojęć jest nieprzypadkowa.

37 Super Philem., 1. 1, nr 9.

38 Por. T. Trigo, Cnoty teologalne w komentarzu św. Tomasza z Akwinu do Listu do Kolosan, s. 306-307. 
do pełnego poznania Boga (J 1,18; J 14,1). Sposób udziału chrześcijan w tej wierze (Flm 1,6) jest podwójny. Od strony treści i przedmiotu wiary, gdy są jednakowe dla wszystkich wyznawców (por. 1 Kor 1,10 ) lub od strony partycypacji w tych samych dobrach ${ }^{39}$.

We wspomnianym wyżej wersecie 6. Akwinata zwraca uwagę na jego moralny wydźwięk. Mianowicie, Apostoł wzywa do ujawnienia wewnętrznej postawy wiary i miłości, czyli do podjęcia działania zgodnego z nią. Przełożenia stanu ontycznego na stan moralny. Rozpoznanie dobra w działaniu jest dwuaspektowe, gdyż dotyczy zarówno rozpoznania dobra, które staje się celem owego działania oraz rozpoznania dobra przez wspólnotę w działaniu konkretnego członka. Dobro to, jeśli jest ukierunkowane ku Chrystusowi nie tylko rozwija chrześcijanina pod względem moralnym, otwiera go na przyjęcie jeszcze większej łaski, ale również buduje i podtrzymuje koinonia we wspólnocie. Taka postawa, którą można by określić mianem „chrystycyzmu” w postępowaniu powinna charakteryzować relacje między członkami Chrystusowego Kościoła. Paweł zwraca uwagę na powyższy fakt zarówno w kontekście dotyczącym tej konkretnej sprawy Filemona i Onezyma, jak i uniwersalnego odniesienia dotyczącego każdego z chrześcijan ${ }^{40}$.

W Flm 1,7 Apostoł Narodów wyraża swoją wielką radość, której bezpośrednią przyczyną jest postawa miłości Filemona wobec członków lokalnej wspólnoty. Paweł miłuje Filemona jak brata i dlatego raduje się, gdy on staje się uczestnikiem i urzeczywistnieniem działania Bożej łaski pośród braćmi ${ }^{41}$. Owocem chrześcijańskiej miłości jest rzeczywista radość, która rodzi się nie tylko w podmiocie, przez który się objawia, ale również udziela się innym członkom wspólnoty eklezjalnej pozostającym w ścisłej relacji do siebie ${ }^{42}$. Dlatego też Apostoł pragnie, aby w tę relację miłości chrześcijańskiej został włączony również Onezym, o czym informuje od wersetu 8 , w którym rozpoczyna się współcześnie wyznaczana cześć zasadnicza listu - prośba w sprawie Onezyma (Flm 1,8-20) ${ }^{43}$.

Św. Paweł swoją prośbę do Filemona zapoczątkowuje od powołania się na zaufanie jakie posiada ze względu na miłość. Źródłem, jak i celem tej miłości

39 Super Philem., 1. 1, nr 9-10.

40 Ibidem, 1. 1, nr. 10; por. też A. Jankowski, Listy Więzienne, s. 320; H. Langkammer, Komentarz teologiczno-pastoralny, s. 331-332; J. Ratzinger, Opera Omnia. Kościót - znak wśród narodów. Pisma eklezjologiczne i ekumeniczne, s. 194, 228.

41 Por. B. Adamczewski, Nowy komentarz, s. 71.

42 Zob. S.Th., II-II, q. 28.

43 Por. B. Adamczewski, Nowy komentarz, s. 74; H. Langkammer, Komentarz teologiczno-pastoralny, s. 333. 
jest Jezus Chrystus ${ }^{44}$. Przez to Apostoł na Nim właśnie opiera swój autorytet do nakazywania czegoś członkom wspólnoty. Jednak ów autorytet w perspektywie miłości funkcjonuje pod pewnymi warunkami, które Akwinata wymienia w swoim komentarzu. Przede wszystkim przełożony jest jakby ojcem dla swoich podwładnych. Podkreśla to chociażby stwierdzenie „zrodzony w wierze”, które św. Tomasz odnosi również do relacji Pawła i Filemona. W związku z tym nakaz przełożonego zawsze winien być ukierunkowany na dobro podwładnego, jak i dobro wspólne całego Kościoła ${ }^{45}$. To powołanie się na miłość przez Pawła jest również skutkiem pewnego podobieństwa między nim a Filemonem w odniesieniu do „stopnia zaawansowania” w cnocie miłości. Wskazuje na to zwrot „stary” (senex), który Apostoł aplikuje nie tylko do siebie. Nie dotyczy on wyłącznie wieku, lecz raczej ugruntowanej postawy chrześcijańskiej (Flm $1,9)^{46}$.

\section{FIm 1,10-25 (nr 15-30)}

W wersecie 10., gdy Paweł wyraził już swoje zaufanie do miłości jaka jest udziałem Filemona, przechodzi do zasadniczej prośby dotyczącej losu Onezyma. W tym miejscu odwołuje się do osobistego związku z nim oraz wspólnych zobowiązań wobec chrześcijańskiej wspólnoty ${ }^{47}$. Ten osobisty związek Apostoł wyraża poprzez nawiązanie do faktu „usynowienia” sługi Filemona. „Zrodzenie" owo ma charakter duchowo-ontyczny oraz moralny. Według Akwinaty wskazuje na to wspomnienie przejścia ze stanu „bezużyteczności” do „użyteczności" nie tylko w wymiarze odniesień osobistych, ale również wspólnotowych. „Bezużyteczność” w tym przypadku oznacza pewnego rodzaju szkodliwość polegającą na pozbawianiu kogoś przynależnych dóbr. „Użyteczność” natomiast jest zwróceniem się ku cnocie miłości, aby w niej służyć Bogu i bliźnim (por. $2 \mathrm{Tm}$ 2,21; Prz 25,4). Ma to być również argument za przebaczeniem słudze, który prawdziwie się nawrócił. Zostanie to jeszcze bardziej wyeksponowane w dalszej części wypowiedzi Pawła Apostoła, gdy powróci do określenia „brat” 48 .

44 S.Th., II-II, q. 26, a. 2.

45 Super Philem., 1. 1, nr 13. O relacjach między chrześcijanami Akwinata piszę więcej na kanwie Ef 5,21-6,9 w: Super Epistolam B. Pauli ad Ephesios lectura, c. 5, 1. 8 - c. 6, 1. 2.

46 Ibidem, 1. 1, nr 14: „cum sis talis, ut Paulus senex” - gdyż jesteś taki, jak starzec Paweł.

47 Por. J.D.G. Dunn, The Epistles, s. 323.

48 Super Philem., 1. 2, nr 15-17. 
Komentarz Tomasza z Akwinu już w prologu zaprezentował te dwa rdzenie chrześcijańskiego braterstwa, które wywodzą się ze wspólnego początku w stwórczym akcie Boga oraz udziału w tej samej miłości duchowej, przez wiarę włączającą chrześcijan w samego Chrystusa. Ta rzeczywistość dotyka zarówno sfery ontycznej, jak i dynamizmu działania w perspektywie nadprzyrodzonej miłości ku braciom. Potwierdzeniem istnienia takiej postawy jest sam św. Paweł, który stawia siebie jako dłużnika wobec Filemona. Nie czyni tego z konieczności, ani nie wykorzystuje faktu, że tenże Filemon sam jest mu dłużny, gdyż przez głoszenie Chrystusa Zmartwychwstałego uratował go przed wieczną śmiercią. Dobrowolnie uznaje się zadośćuczynić za Onezyma w imię przyjaźni (amor amicitiae), którą żywi wobec braci w wierze (por. Ga 6,2) ${ }^{49}$. Pomimo pewnego retorycznego oraz prawniczego charakteru jego wypowiedzi w Flm 1,17-19 przekaz Apostoła ma na celu ukazanie znaczenia wartości duchowych nad materialnymi w chrześcijańskim życiu oraz relacji, jakie rodzą się na tej bazie ${ }^{50}$. W wersecie 20. św. Paweł ponownie mówi o radości, co nawiązuje do Flm 1,7. Przedstawia swoją prośbę, której zrealizowanie będzie kontynuowało jego stan rozradowania się postępowaniem Filemona wobec braci. Tomasz z Akwinu opowiadając o tej chrześcijańskiej radości odnosi się do obrazu słodkiego owocu (por. Pnp 2,3). Dobre działanie w sposób celowy przynosi dobry owoc, z którego można korzystać i cieszyć się nim. Dzięki mocy miłości działającej pomiędzy przyjaciółmi takie dobre działanie drugiego może zostać przyjęte jako własne i stać się źródłem radości. Radość jest nie tylko skutkiem urzeczywistnionego dobra, ale również celem. Już sama nadzieja na jego osiągnięcie dla siebie oraz drugiego jest powodem rozradowania. Do pełni jednak potrzeba gwaranta, który stanie się ostatecznym przedmiotem owej radości. Takim może być tylko Bóg ${ }^{51}$. Przez to chrześcijańska radość nabiera transcendentnego charakteru, jednocześnie przekraczającego wymiar doczesności, ale też nieustannie odwołującego się do niego.

Werset 21. rozpoczyna sekcje kończącą cały list, w której błogosławiony autor umieszcza ostatnie polecenia i pozdrowienia. W ww. 21-22 Apostoł odwołuje się do zaufania jakie posiada wobec poczynań Filemona. W tym miejscu Tomasz z Akwinu zwraca uwagę na dwie kwestie: przedmiotu ufności oraz niezrealizowania się pewnej nadziei. Akwinata stwierdza, że św. Paweł jest ufny (confidens) wobec posłuszeństwa (obedientia) swojego brata, które dotychczas zawsze mu okazywał. Ze względu jednak na swoją funkcję apostolską oraz troskę o relacje we wspólnocie w Kolosach, dodaje prośbę o przygotowanie gości-

49 Ibidem, 1. 2, nr 24-25. Zob. też S.Th., II-II, q. 62, a. 4 i 7.

50 Por. H. Langkammer, Komentarz teologiczno-pastoralny, s. 342-343.

51 Super Philem., 1. 2, nr 28; S. Th., II-II, q. 32, a. 5-6. 
ny. Dla Doktora Anielskiego powodem tego jest reguła, według której polecenia osób są gorliwiej wysłuchiwane, gdy istnieje możliwość ich ponownego spotkania. Za Janem Chryzostomem ${ }^{52}$, bynajmniej nie chodzi Apostołowi o jakieś konkretne rzeczy zewnętrzne, lecz o podkreślenie adresatowi faktu głębokiej zażyłości i związania wspólną miłością do Chrystusa. To one mają być podstawą jego posłuszeństwa. Bardziej problematyczne dla św. Tomasz wydaje się jednak odniesienie do faktów, które wyczytał z treści Dziejów Apostolskich oraz pozostałych Listów Pawła. Mianowicie, nadzieja Apostoła okazała się próżna (defecit), gdyż ze względu na śmierć nie powrócił już nigdy do kościoła gromadzącego się w domu Filemona. Jednakowoż nadzieja chrześcijańska najpierw za przedmiot ma dobro właściwe (bonum proprium), a drugorzędnie wystawienie innych na próbę. Odnośnie do pierwszego nadzieja nie zawodzi nigdy, natomiast co do drugiego może okazać się zawodna, gdyż działania innych bywają z nią sprzeczne. Poza tym nikt oprócz Boga nie posiada poznania spraw przyszłych co do dobra danego człowieka, dlatego nawet modlitwy w czyjejś intencji pozostają czasami jakby niewysłuchane $e^{53}$.

Co interesujące w zakończeniu swojego komentarza Doktor Anielski umieszcza pewne dywagacje dotyczące umiejscowienie Listu do Filemona w układzie całego korpusu epistolarnego Pawła Apostoła. Na podstawie zestawionych z sobą informacji pochodzących z różnych listów ustala, że List do Filemona powstał na początku uwięzienia Apostoła w Rzymie, przed Drugim Listem do Tymoteusza. Konkludując, List do Filemona, tak jak każdy inny list św. Pawła nie jest uszeregowany w kanonie ze względu na czas powstania, lecz na doniosłość treści, którą sobą przekazuje $\mathrm{e}^{54}$.

\section{Podsumowanie}

W świetle Super Epistolam ad Philemonem lectura treść Listu św. Pawła Apostoła odsłania znaczenie, które niekoniecznie nawiązuje do nowożytnych ujęć egzegetycznych. Akwinata niewystarczająco dotyka zagadnień interesujących współczesnych, czyli spraw związanych z kościołem domowym oraz stosunkiem chrześcijan do niewolnictwa. Doktor Anielski na bazie relacji sługa - pan, którą widzi w perspektywie chrześcijańskiego braterstwa akcentuje obecność czynnika konstytuującego bycie chrześcijaninem, mianowicie Łaskę Ducha

52 Akwinata w swoim komentarzu parafrazuje początek III Homilii Jana Chryzostoma do Listu do Filemona.

53 Super Philem., 1. 2, nr 29.

54 Ibidem, 1. 2, nr 30. 
Świętego. Jest ona obecna zarówno przy nastaniu tego nowego statusu ontycznego (łaska habitualna), jak i w dynamice chrześcijańskiej egzystencji (łaski aktualne). Przez Tomasza z Akwinu w charakterystyczny dla niego sposób łaska zostaje ujęta w zagadnienie „nowego prawa” ${ }^{55}$. Parafrazując nauczanie Akwinaty Marie-Dominique Chenu napisał: „Nowe prawo, to znaczy sama Ewangelia, jest to prawo wpisane w sercu. W rzeczy samej wszelka rzeczywistość istnieje i jest określana przez to, co w niej jest najważniejsze. Otóż tym, co w prawie Nowego Przymierza jest najważniejsze i na czym się zasadza cała jego moc, jest łaska Ducha Świętego, którą otrzymujemy przez wiarę w Chrystusa. Zatem nowe prawo jest w swej istocie łaską Ducha Świętego udzielanego wierzącym" ${ }^{\prime \prime 6}$. Łaska bowiem jest „śladem” Ducha objawiającego swoją obecność w chrześcijaninie. Obecność tą potwierdza działanie według Jego poruszeń, które nie są zniewalające i dezintegrujące dla ludzkiej natury, lecz wynoszą ją do nadprzyrodzonego udziału w trynitarnym życiu Boga ${ }^{57}$. Dlatego też, na fundamencie nauki Apostoła Narodów Tomasz z Akwinu przedstawia międzyludzkie braterstwo, które pierwszorzędnie pochodzi z natury, natomiast dla chrześcijan posiada również charakter nadnaturalny. Te dwie rzeczywistość natury i łaski w chrześcijańskiej egzystencji nie powinny być rozrywane, ale winny razem współbrzmieć dla osiągnięcia celu, jakim jest szczęście. Dopomóc w tym ma praktykowanie cnót uzdalnianych przez łaskę do przekraczania granic powinności i wchodzenia w rzeczywistość Chrystusowej miłości, czyli poświęcenia swojego życia dla drugiego ${ }^{58}$. Nakreślony przez Świętego Pawła obraz wspólnotowych relacji pomiędzy Apostołem, Filemonem i Onezymem poucza o potrzebie nieustannego trwania w postawie prawdziwie chrześcijańskiej, gdyż tylko taka postawa, której istotę stanowi ontyczno-moralna wspólnota miłości z Trójosobowym Bogiem, jest w stanie odpowiednio je uporządkować i nadać im właściwy sens. Ową postawę prawdziwie chrześcijańską stara się wydobywać oraz opisywać na różne sposoby właśnie chrystianologia. Powyższy artykuł stanowił jedną z prób podejścia do treści Listu do Filemona, jako źródła chrystianologii Pawła Apostoła.

55 Zob. M. Dauphinais, M. Levering, Knowing the Love of Christ, s. 61-75.

56 M.-D. Chenu, Święty Tomasz z Akwinu i teologia, tłum. W. Szymona, A. Ziernicki, Kraków 1997, s. 81.

57 Por. J.L. Lorda, Łaska Boża, s. 202-203; M. Mróz, Pawłowe „Prawo Ducha”, s. 34. Zob. też F.Ch. Bauerschmidt, Thomas Aquinas. Faith, Reason, and Following Christ, s. 147-258; E. Kaczyński, „Prawo Ducha” u św. Tomasza, s. 35-37; M. Levering, Paul in the Summa Theologiae, s. 169.

58 Por. M. Mróz, By nie zniweczyć Chrystusowego krzyża (1 Kor 1,17), s. 110-112. 


\section{Bibliografia}

\section{Źródła}

S. Thomae Aquinatis, Super Epistolas S. Pauli lectura, t. 2, Super Epistolam B. Pauli ad Colossenses lectura, ed. R. Cai, 8 a ed., Marietti, Taurini-Romae 1953.

S. Thomae Aquinatis, Super Epistolas S. Pauli lectura, t. 2, Super Epistolam B. Pauli ad Philemonem lectura, ed. R. Cai, 8 ${ }^{\text {a }}$ ed., Marietti, Taurini-Romae 1953.

S. Thomae Aquinatis, Super Epistolas S. Pauli lectura, t. 2, Super Epistolam B. Pauli ad Philipenses lectura, ed. R. Cai, $8^{\text {a }}$ ed., Marietti, Taurini-Romae 1953.

Sancti Thomae Aquinatis, Opera omnia iussu Leonis XIII P.M. edita, t. 25/1, Préface. Quaestiones de quolibet. Quodlibet VII, VIII, IX, X, XI, Roma-Paris 1996.

Sancti Thomae Aquinatis, Opera omnia iussu Leonis XIII P.M. edita, t. 4-12, Summa theologiae, Roma 1888-1906.

\section{Opracowania i komentarze}

Adamczewski B., Nowy komentarz biblijny. List do Filemona, List do Kolosan, Częstochowa 2006.

Bauerschmidt F.Ch., Thomas Aquinas. Faith, Reason, and Following Christ. Christian Theology in Context, Oxford 2013.

Cantalamessa R., „Litera zabija, Duch ożywia”. Lektura duchowa Biblii, w: Słowo Boże $w$ życiu i misji Kościoła, S. Szymik (red.), Lublin 2009, s. 273-285.

Chenu M.-D., Święty Tomasz z Akwinu i teologia, tłum. W. Szymona, A. Ziernicki, Kraków 1997.

Dauphinais M., Levering M., Knowing the Love of Christ. An Introduction to the Theology od St. Thomas Aquinas, Notre Dame 2011.

Dunn J.G., The Epistles to the Colossians and to Philemon. A Commentary on the Greek Text, NIGTC, Grand Rapids 1996.

Gałuszka T., Badania nad Biblia w XIII wieku. Super Psalmum XXIII, Kraków 2005.

Gnilka J., Paweł $z$ Tarsu. Apostoł $i$ świadek, tłum. W. Szymona, Kraków 2001.

Hanusek M., Komentarz św. Tomasza z Akwinu do Listu do Filemona, Przegląd Tomistyczny 15 (2009), s. 93-119.

Haręzga S., En Pneumati jako zasada interpretacji Pisma św. we wschodniej tradycji Kościoła, Ruch Biblijny i Liturgiczny 43 (1990), s. 111-121.

Healy M., Aquinas's Use of the Old Testament in His Commentary on Romans, w: Reading Romans with St. Thomas Aquinas, M. Dauphinais, M. Levering (eds.), Washington D.C. 2013, s. 183-195.

Jankowski A., Listy Więzienne Świętego Pawła, KUL, t. 8, Poznań 1962.

Kaczyński E., „Prawo Ducha” u św. Tomasza, W Drodze 7 (1984), s. 35-41.

Langkammer H., Komentarz teologiczno-pastoralny wszystkich listów św. Pawła Apostoła z okazji roku Świętego Pawła. Listy Więzienne św. Pawła, t. 2, Legnica 2010. 
Levering M., Ecclesial Exegesis and Ecclesial Authority: Childs, Fowl and Aquinas, The Thomist 69/3 (2005), s. 407-467.

Levering M., Paul in the Summa Theologiae, Washington D.C. 2014.

Lorda J., Łaska Boża, tłum. J. Lekan, Lublin 2012.

Mróz M., By nie zniweczyć Chrystusowego krzyża (1 Kor 1,17). Zrozumienie misterium męki i śmierci Jezusa $w$ świetle niektórych elementów chrystianologii moralnej św. Tomasz z Akwinu, Teologia i Człowiek 11 (2008), s. 101-124.

Mróz M., Nova vita in Christo. Elementy chrystianologii moralnej św. Tomasza z Akwinu w świetle Wykładu Listu do Kolosan, w: Tomasz z Akwinu, Wykład Listu do Kolosan. Super Epistolam B. Pauli ad Colossenses lectura, tłum. P. Roszak (red.), Toruń 2012, s. 321-356.

Mróz M., Pawłowe „Prawo Ducha” (Rz 8,2) kluczem do zrozumienia myśli św. Tomasza z Akwinu o istocie Ewangelii, Teologia i Człowiek 17 (2011), s. 29-41.

Mróz M., Roszak P., Tomasza z Akwinu ideat egzegety i podstawy jego pracy in Sacra Pagina, Teologia i Człowiek 10 (2007), s. 113-130.

Pinckaers S.T., Życie duchowe chrześcijanina według św. Pawła i św. Tomasza z Akwinu, tłum. A. Fabiś, Poznań 1998.

Ratzinger J., Opera Omnia. Kościół - znak wśród narodów. Pisma eklezjologiczne i ekumeniczne, t.8/1, tłum. W. Szymona, Lublin 2013.

Rehfeld E.L., Relationale Ontologie bei Paulus: die ontische Wirksamkeit der Christusbezogenheit im Denken des Heidenapostels, Tübingen 2012.

Roszak P., Autorytet w poszukiwaniu mądrości. Wokół konceptu auctoritas w teologii św. Tomasza z Akwinu, Człowiek w Kulturze 22 (2011/2012), s. 67-90.

Roszak P., Between Dialectics and Metaphor. Dynamics of Exegetical Practice of Thomas Aquinas, Angelicum 90 (2013), s. 507-534.

Roszak P., Exegesis y metafisica. En torno a la hermeneutica biblica de santo Tomas de Aquino, Salmanticensis 61 (2014), s. 301-323.

Roszak P., The Place and Function of Biblical Citations in Thomas Aquinas's Exegesis, w: Reading Sacred Scripture with Thomas Aquinas: Hermeneutical Tools and New Perspectives, R. Roszak, J. Vijgen (eds.), 2015 [w druku].

Roszak R., Słowo od redaktora, Biblia i metafizyka: ku tomizmowi biblijnemu, w: Tomasz z Akwinu, Wykład Listu do Kolosan, Super Epistolam B. Pauli ad Colossenses lectura, tłum. P. Roszak (red.), Toruń 2012, s. 9-21.

Sirilla M.G., St. Thomas Aquinas's Theology of the Episcopacy in his Commentaries on the Pastoral Epistles, Washington, D.C. 2008.

Szymik S., Współczesne modele egzegezy biblijnej, Lublin 2013.

Świerzawski W., Egzegeza spekulatywna i teologia spekulatywna św. Tomasza z Akwinu, Znak 22/187 (1970), s. 27-41.

Torrell J-P., Tomasz z Akwinu - człowiek i dzieło, tłum. A. Kuryś, Kęty-Warszawa 2008.

Trigo T., Cnoty teologalne w komentarzu św. Tomasza z Akwinu do Listu do Kolosan, w: Tomasz z Akwinu, Wykład Listu do Kolosan. Super Epistolam B. Pauli ad Colossenses lectura, tłum. P. Roszak (red.), Toruń 2012, s. 293-320.

Weisheipl J., Tomasz z Akwinu. Życie, myśl i dzieło, tłum. Cz. Wesołowski, Poznań 1985. Zdziarstek R.S., Chrystianolgia Świętego Pawła, Aspekt ontyczny, t. I, Kraków 1989. 